\title{
MENAFSIRKAN AL-QUR'AN Mengkaji Metode, Bentuk, dan Kaidah-Kaidah dalam Penafsiran Al-Qur'an
}

\author{
Mibtadin \\ Institut Islam Mamba'ul 'Ulum Surakarta \\ e-mail: mibtadinanisahmad@gmail.com
}

\begin{abstract}
Abstrak: Al-Qur'an sebagai kitab suci umat Islam merupakan sumber hukum dan petunjuk serta menjelaskan segala sesuatunya secara komprehensif dan metode praktis bagi kehidupan. Oleh karena itu perlu adanya ilmu perlu adanya ilmu tafsir dengan maksud agar menuntut para mufasir dalam proses penafsiran al-Quran sehingga tidak keluar dari apa yang dimaksudkan oleh al-Qur'an sendiri. Selain itu mufasir mengerti kaidah-kaidah yang harus dipakai dalam penafsiran, serta dituntut menguasai/memahami jati diri al-Qur'an baik itu bentuk penafsiran (tafsir bi al- ma'tsur, tafsir bi alra'yi, dan tafsir isyari), metode (ijmali, muqarin, maudhu'i, tahlili), corak dan juga kepribadian yang luhur, baik dan bertanggungjawab. Selain itu tafsir dan ta'wil yang ada sejak zaman Rasulullah saw seiring dengan kemajuan zaman bermunculan metode pendekatan baru dalam memahami al- Qur'an seperti: hermeneutik dan pendekatan kajian analisis bahasa (linguistik), yaitu semiotik.
\end{abstract}

Kata kunci: Al-Qur'an, metode, bentuk, kaidah, penafsiran

\section{PENDAHULUAN}

Al-Qur'an diturunkan kepada Nabi Muhammad saw melalui malaikat Jibril dalam bahasa Arab dengan segala macam kekayaan bahasanya. Al-Qur'an al-Karim, yang merupakan sumber utama ajaran Islam, berfungsi sebagai "Petunjuk ke jalan yang sebaikbaiknya" (huda li an-naas) (Qs. 17: 9) demi kebahagiaan hidup manusia di dunia dan akhirat. ${ }^{1}$ petunjuk-petunjuk tersebut banyak yang bersifat umum dan global, sehingga penjelasan dan penjabarannya dibebankan kepada Nabi Muhammad saw (Qs. 16: 44; 4: 105 dan sebagainya), yang di dalamnya terdapat penjelasan mengenai dasar-dasar aqidah, kaidah- kaidah syari'at, asas-asas perilaku yang menuntun manusia ke jalan yang lurus dalam berpikir dan beramal. Namun Allah swt tidak menjamin perincian-perincian dalam masalah-masalah itu sehingga banyak lafazh al-Qur'an yang membutuhkan tafsir, apalagi sering digunakan susunan kalimat yang singkat namun luas pengertiannya. Dalam lafazh yang sedikit saja dapat terhimpun sekian banyak makna.

Penafsiran terhadap al-Qur'an menjadi sangat penting, mengingat kemampuan setiap orang dalam memahami lafazh dan ungkapan al-Qur'an tidak sama, kalangan awam hanya dapat memahami makna-makna yang dhahir, seperti ayat-ayat yang global; sedangkan kaum cendekia mampu menyelami makna kandungan al-Qur'an secara mendalam. ${ }^{2}$ Maka tidak mengherankan jika al-Qur'an mendapatkan perhatian besar dari umatnya melalui pengkajian intensif terutama dalam rangka penafsiran al-Qur'an untuk mendapatkan kebahagiaan,

\footnotetext{
${ }^{1}$ Thameem Ushama, Metodologi Tafsir al-Qur'an, Kajian Kritis, Objektif \& Komprehensif (Jakarta: Rineka Cipta, 2000), hlm. 2

${ }^{2}$ Manna Khalil al-Qattan, Studi Ilmu-Ilmu al-Qur'an, Terj. Mudzakir AS. Cet. Ke-V, (Bogor: Pustaka Litera Antarnusa, 1996), hlm. 455.
} 
pengetahuan, dan menyingkap rahasia-rahasia dan makna-makna yang terkandung di dalamnya. Oleh karena itu, makalah ini mencoba untuk berbicara seputar masalah penafsiran al-Qur'an; baik itu sejarah perkembangan ilmu tafsir, metode, dan bentuk, dan kaidah penafsiran ayat-ayat al-Qur'an.

\section{PEMBAHASAN}

\section{Sejarah dan Perkembangan Penafsiran al-Qur'an}

Sejarah ini diawali dengan masa Rasulullah saw masih hidup seringkali timbul beberapa perbedaan pemahaman tentang makna sebuah ayat. Untuk itu mereka dapat langsung menanyakan pada Rasulullah saw. Secara garis besar ada tiga sumber utama yang dirujuk oleh para sahabat dalam menafsirkan al-Qur'an: Pertama, al-Qur'an itu sendiri karena terkadang satu hal yang dijelaskan secara menyeluruh di satu tempat dijelaskan secara lebih terperinci di ayat lain. Kedua, Rasulullah saw semasa masih hidup para sahabat dapat bertanya langsung pada Beliau saw tentang makna suatu ayat yang tidak mereka pahami atau mereka berselisih paham tentangnya. Ketiga, ijtihad dan pemahaman mereka sendiri karena mereka adalah orang-orang Arab asli yang sangat memahami makna perkataan dan mengetahui aspek kebahasaannya. Tafsir yang berasal dari para sahabat ini dinilai mempunyai nilai tersendiri menurut jumhur ulama karena disandarkan pada Rasulullah saw terutama pada masalah asbab an-nuzul. Sedangkan pada hal yang dapat dimasuki ra'yi maka statusnya terhenti pada sahabat itu sendiri selama tidak disandarkan pada Rasulullah saw. ${ }^{3}$

Pada masa awal turunnya al-Qur'an, Rasulullah saw juga yang berfungsi sebagai mubayyin (pemberi penjelasan), menjelaskan kepada sahabat-sahabatnya tentang arti dan kandungan al-Qur'an, khususnya menyangkut ayat-ayat yang tidak dipahami atau samar artinya. Keadaan ini berlangsung sampai dengan wafatnya Rasulullah saw, walaupun harus diakui bahwa penjelasan tersebut tidak semua kita ketahui akibat tidak sampainya riwayatriwayat tentangnya atau karena memang Rasulullah saw sendiri tidak menjelaskan semua kandungan al-Qur'an. Kalau pada masa Rasulullah saw para sahabat menanyakan persoalanpersoalan yang tidak jelas kepada Beliau, maka setelah wafatnya, mereka terpaksa melakukan ijtihad, khususnya mereka yang mempunyai kemampuan. ${ }^{4}$

Rasullah saw sebagai penjelas dan penafsir (Qs. 16: 44), banyak menimbulkan perbedaan pendapat, apakah Rasulullah menjelaskan seluruh makna lafadz di dalam alQur'an atau hanya sebagian saja. Ibn Taimiyyah berpandangan bahwa Rasulullah menjelaskan seluruh makna lafadz di dalam al-Qur'an, mengingat posisinya sebagai mubayyin; sedang al-Suyuthi dan al-Khuwayyi beranggapan bahwa Rasulullah tidak menjelaskan seluruh makna lafadz di dalam al-Qur'an. Dalam hal ini al-Dzahabi, mengungkapkan lima hal yang dilakukan Rasulullah dalam memahami al-Qur'an; pertama, menjelaskan hal-hal yang umum dalam al-Qur'an; kedua, menjelaskan makna sebuah lafadz dan konotasinya; ketiga, menjelaskan hukum-hukum tambahan selain yang sudah tercantum

\footnotetext{
${ }^{3}$ Muhammad Husein al-Dzahabi, al-Ijjitahat al-Munhariffah fi Tafsir al-Qur'an. Cet. Ke-2 (Kuwait: tp, 1978), hlm. 11.

${ }^{4}$ Muhammad Hasbi ash-Shiddiqiey, Ilmu-Ilmu al-Qur'an. Media-Media Pokok Dalam Menafsirkan alQur'an (Jakarta: Bulan Bintang, 1993), hlm. 199
} 
di dalam al-Qur'an, seperti nikah, waris, zina, dan lainnya. Keempat, menjelaskan abrogasi; kelima, sebagai penguatan terhadap al-Qur'an. ${ }^{5}$

Setelah Rasulullah wafat, tidak dapat dihindari para sahabat mempunyai pemahaman dan penafsiran yang berbeda (Qs. 8: 46), karena penafsiran yang dilakukan oleh para sahabat pada dasarnya mengembangkan tradisi penafsiran yang telah dilakukan oleh Rasulullah serta sesuai dengan kecerdasan nalar parasahabat. ${ }^{6}$ Ada diantara kalangan para sahabat yang terkenal banyak menafsirkan al-Qur'an antara lain empat khalifah (Abu Bakar ash-Shidiq, Umar ibn Khaththab,Usman bin Affan, dan Ali bin Abi Thalib), Ibn Mas'ud, Ibn Abbas, Ubai bin Ka'ab, Zaid bin Tsabit, Abu Musa al-Asy'ari, Abdullah bin Zubair, Aisyah, Anas bin Malik, Abu Hurairah, Abdullah bin Umar, Jabir bin Abdullah, Abdullah bin 'Amr bin 'Ash, dan lainnya. ${ }^{7}$ Pada masa sahabat ini belum terdapat satupun pembukuan tentang tafsir dan masih bercampur dengan hadits.

Sesudah generasi sahabat, datanglah generasi tabi'in yang belajar Islam melalui para shahabat di wilayah masing-masing. Para mufassir bermunculan dari kalangan tabi'in antara lain: Mujahid ibn Jabir Atha ibn Abi Ribah, Ikrimah Maula Ibn Abbas, Thaus ibn Kisan alYamani dan Said ibn Jabir, Muhammad ibn Ka'ab al-Qurazhi, Abu al-Aliyah ar-Riyahi dan Zaid ibn Aslam, al-Hasan al- Bashri, Masruq ibn al-Ajda Qatadah ibn-Di'amah, Atah ibn Abi Muslim al- Khurasani dan Marah al-Hamdani. ${ }^{8}$ Pada masa ini tafsir merupakan bagian integral dari hadits namun, masing-masing tabi'in meriwayatkan dari guru mereka sendirisendiri. Ketika datang masa kodifikasi hadis, riwayat yang berisi tafsir sudah menjadi bab tersendiri namun belum sistematis sampai masa sesudahnya ketika pertama kali dipisahkan antara kandungan hadis dan tafsir sehingga menjadi kitab tersendiri. Usaha ini dilakukan oleh para ulama sesudahnya seperti Ibn Majah, Ibn Jarir at-Thabari, Abu Bakr ibn al-Munzir an Naisaburi dan lainnya. Metode pengumpulan inilah yang kemudian disebut sebagai bentuk tafsir bi al-matsur.

Perkembangan ilmu pengetahuan pada masa Dinasti Abbasiyah menuntut pengembangan metodologi tafsir dengan memasukkan unsur ijtihad yang lebih besar. Meskipun begitu mereka tetap berpegangan pada tafsir bi al-matsur dan metode lama dengan pengembangan ijtihad berdasarkan masa tersebut. Hal ini melahirkan apa yang disebut sebagai tafsir bi al-ra'y yang memperluas ijtihad dibandingkan masa sebelumnya. ${ }^{9}$ Lebih lanjut perkembangan ajaran tasawuf melahirkan pula sebuah tafsir yang biasa disebut sebagai tafsir isyarah. Ilmu tafsir al-Qur'an terus mengalami perkembangan sesuai dengan tuntutan zaman. Perkembangan ini merupakan suatu keharusan agar al-Qur'an dapat bermakna bagi umat Islam. Pada perkembangan terbaru mulai diadopsi metode-metode baru guna memenuhi tujuan tersebut. Dengan mengambil beberapa metode dalam ilmu filsafat yang digunakan untuk membaca teks al-Qur'an maka dihasilkan cara-cara baru dalam

\footnotetext{
${ }^{5}$ Zuhairi Misrawi, Al-Qur'an Kitab Toleransi. Inklusivisme, Pluralisme dan Multikulturalisme (Jakarta: Penerbit Fitrah, 2007), hlm. 134.

${ }^{6}$ Muhammad Husein al- Dzahabi, al-Ijjitahat al-Munhariffah...., Ibid., hlm. 46.

${ }^{7}$ Jamaluddin Abdurrahman al-Suyuthi, al-Itqan fi 'Ulum al-Qur'an (Kairo: Dar al- Hadits, 2004), hlm. 303.

${ }^{8}$ M. Hasbi ash-Shiddiqiey, Ilmu-Ilmu al-Qur'an,..hlm. 194.

${ }^{9}$ Muhammad Husayn al-Dhahabi, Al-Ijtihad al-Munharifat fi Tafsir al-Qur'an al-Karim. Firs Edition (tanpa kota: Dar al-I'tisam, 1976), hlm. 153
} 
memaknai al-Qur'an. Diantara metode-metode tersebut yang cukup populer antara lain adalah Metode Tafsir Hermeneutik dan Metode Tafsir Semiotika.

\section{Ragam Metodologi Penafsiran Al-Qur'an}

Metodologi penafsiran merupakan ilmu yang membahas tentang tata cara yang teratur dan terpikir baik-baik untuk mendapatkan pemahaman yang benar dari ayat-ayat al-Qur'an sesuai kemampuan manusia. ${ }^{10}$ Definisi tersebut memberikan gambaran kepada kita metodologi tafsir berisi pembahasan ilmiah tentang metode atau cara yang dapat digunakan oleh mufassir dan sekaligus akan menuntunnya dalam proses penafsiran al-Qur'an, sehingga penafsirannya tidak keluar dari jalan yang benar. Definisi diatas memberikan deskripsi bahwa metodologi tafsir berisi pembahasan ilmiah tentang metode atau cara yang digunakan oleh mufassir dan sekaligus untuk menuntunnya dalam proses penafsiran al-Qur'an, baik itu yang berupa aturan-aturan teknis maupun teoritis- konseptual. Jika ditelusuri perkembangan tafsir al-Qur'an sejak dulu sampai sekarang, maka secara garis besarnya penafsiran al-Qur'an dilakukan dalam empat cara/metode yaitu metode ijmali (global), metode tahlili (analitis), metode mawdhu'i (tematik), dan metode muqarin (perbandingan).

A. Metode Ijmali (Global)

Metode Ijmali adalah berusahan menafsirkan/menjelaskan ayat-ayat al- Qur'an secara singkat dan global, dengan menjelaskan makna yang dimaksud tiap kalimat dengan bahasa yang ringkas sehingga mudah dipahami. Sistematikanya menuruti susunan ayat-ayat di dalam mushaf, di samping itu penyajiannya tidak terlalu jauh dari gaya bahasa al-Qur'an sehingga pendengar dan pembacanya seakan-akan masih tetap mendengar al-Qur'an, padahal yang didengarnya adalah tafsirannya. ${ }^{11}$ Kelebihan dari metode tafsir ini ada pada kemudahannya sehingga dapat dikonsumsi oleh lapisan dan tingkatan kaum muslimin secara merata, sedangkan metode ini mempunyai kelemahan pada penjelasannya yang terlalu ringkas sehingga tidak dapat menguak makna ayat yang luas dan tidak dapat menyelesaikan masalah secara tuntas. Metode ijmali dalam penafsirannya, mufasir langsung menafsirkan alQur'an dari awal sampai akhir tanpa perbandingan (muqarin) dan penetapan judul (mawdhu'i), dan tidak terlalu rinci (tahlili); sebab dalam metode ijmali ini tidak ada ruang yang cukup untuk mufasir mengemukakan pendapat yang berlebihan dalam penafsirannya. Kitab Tafsir al-Qur'an al-Karim (karya Muhammad Farid Wajdi), al-Tafsir al-Wasith terbitan Majma' al-Buhuts al-Islamiyyat, Tafsir Jalalain, serta Taj al-Tafasir karangan Muhammad Usman al-Mirghani termasuk kategori metode tafsir ini. ${ }^{12}$

B. Metode Tahlili (Analitik)

Metode Tahlili adalah metode menafsirkan ayat-ayat al-Qur'an yang berusaha menjelaskan/memaparkan al-Qur'an dengan menguraikan segala aspek yang terkandung di dalam ayat-ayat yang ditafsirkan itu serta menerangkan makna-makna yang tercakup di dalamnya sesuai dengan keahlian dan kecenderungan mufasir yang menafsirkan ayat-ayat

\footnotetext{
${ }^{10}$ Nashruddin Baidan, "Rekonstruksi Ilmu Tafsir", dalam Pidato Pengukuhan Guru Besar Madya Ilmu Tafsir. Surakarta: 1999) hlm. 48

${ }^{11}$ Nashruddin Baidan, "Rekonstruksi Ilmu Tafsir.., hlm. 67.

${ }^{12}$ Abd al-Hayy al-Farmawi. Metode Tafsir Mawdhu'i. Suatu Pengantar. Terj. Suryan A. Jumrah, Cet. Ke-2. (Jakarta: Raja Grafindo, 1996). Hlm. 43.
} 
tersebut. ${ }^{13}$ Dalam metode ini, mufasir menguraikan makna yang dikandung dalam al-Qur'an secara komprehensif, menyeluruh, dan mendalam; baik itu ayat demi ayat, surat demi surat sesuai dengan urutan yang ada dalam mushaf. Adapun uraian tersebut menyangkut aspek yang dikandung ayat yang ditafsirkan, seperti pengertian kosakata, konotasi kalimat, asbab an-nuzul, munasabah ayat, serta pendapat- pendapat yang berkaitan dengan ayat yang ditafsirkan tersebut, baik itu dari nabi, sahabat, tabi'in maupun ahli tafsir lainnya.

Adapun kelemahan lain dari metode ini adalah bahwa bahasan-bahasannya amat teoritis, tidak sepenuhnya mengacu kepada persoalan-persoalan khusus yang mereka alami dalam masyarakat mereka, sehingga mengesankan bahwa uraian itulah yang merupakan pandangan al-Qur'an untuk setiap waktu dan tempat. Hal ini dirasa terlalu "mengikat" generasi berikutnya. Dapat ditambahkan bahwa para penafsir yang menggunakan metode itu tidak jarang hanya berusaha menemukan dalil atau lebih tepat dalih pembenaran pendapatnya dengan ayat-ayat al-Qur'an. Selain itu, terasa sekali bahwa metode ini tidak mampu memberi jawaban tuntas terhadap persoalan-persoalan yang dihadapi sekaligus tidak banyak memberi pagar-pagar metodologis yang dapat mengurangi subjektivitas mufasirnya. ${ }^{14}$ hal ini mungkin karena sifat penafsirannya amat teoritis, tidak sepenuhnya mengacu kepada penafsiran persoalan-persoalan khusus yang mereka alami dalam masyarakat mereka, sehingga uraian yang bersifat teoritis dan umum itu mengesankan bahwa itulah pandangan al-Qur'an untuk setiap waktu dan tempat.

Adapun beberapa kitab tafsir yang mengambil metode ini dalam bentuk bial-Ma'tsur adalah: Jami al-Bayan al-Bayan fi Tafsir al-Qur'an al-Karim/Tafsir al-Thabari karya Ibnu Jarir al-Thabari (w.310 H). Ma'alim al-Tanzil karangan al- Baghawi (w.516 H), Tafsir alQur'an al- 'Azhim/Tafsir bi al-Ma'tsur karya as- Suyuthi (w. 911 H), Tafsir ibn Katsir karya Ibn Katsir (w. 774). Sedangkan yang mengambil bentuk ar-ra'yi antara lain: Tafsir al-Khazin karya al-Khazin (w.741 H), Anwar al-Tanzil wa Asrar al-Ta'wil karangan al-Baydhawi (w. 691 H), al-Kasysyaf karya al-Zamakhsyari (w. 538 H), al-Tafsir al-Kabir wa Mafatih alGhaib karya Fakhr ar-Razi (w. 606), al-Jawahir fi Tafsir al-Qur'an karangan Thanthawi alJauhari; Tafsir al-Manar oleh M. Rasyid Ridha, 'Arais al-Bayan fi Haqaiq al-Qur'an karangan al-Syirazi (w. $606 \mathrm{H})^{15}$ dan masih banyak lagi.

C. Metode Maudhu'i (Tematik)

Metode maudhu'i adalah metode tafsir yang berusaha mencari jawaban al- Qur'an dengan cara mengumpulkan ayat-ayat al-Qur'an yang mempunyai tujuan satu, yang bersamasama membahas topik atau judul tertentu dan menertibkannya sesuai dengan masa turunnya selaras dengan sebab-sebab turunnya, kemudian memperhatikan ayat-ayat tersebut dengan penjelasan-penjelasan, keterangan- keterangan dan hubungan-hubungannya dengan ayat-ayat lain kemudian dikaji secara mendalam dan tuntas dari berbagai aspek serta didukung dengan dalil-dalil atau fakta yang dapat dipertanggungjawabkan secara ilmiah; baik argumen itu berasal dari al-Qur'an, hadis maupun dari pemikiran rasional yang kemudian mengambil

\footnotetext{
${ }^{13}$ M. Quraisy Shihab, “Tafsir al-Qur'an Dengan Metode Mawdhu'i”,dalam Beberapa Aspek Ilmiah Tentang al-Qur'an.

${ }^{14}$ Nashruddin Baidan, Metodologi Penafsiran al-Qur'an, Cet. Ke-1 (Yogyakarta: Pustaka Pelajar, 1998), hlm. 53

${ }^{15}$ Nashruddin Baidan, Rekonstruksi Ilmu Tafsir., hlm. 56
} 
hukum-hukum darinya. ${ }^{16}$ Diantara kitab tafsir yang masuk dalam kategori metode ini adalah; al-Insan fi al-Qur'an, dan Marat fi al-Qur'an karangan Muhammad al-'Aqqad serta alRiba'fi al-Qur'an karya al-Mawdudi.

Sebagai metode tafsir topikal, tidak mengherankan jika dalam pembahasannya sangat menonjolkan tema, judul atau topik pembahasan, baik yang diambil dari masyarakat maupun tema dari al-Qur'an itu sendiri, ataupun dari yang lainnya. Kemudian tema-tema yang dipilih tersebut dikaji secara tuntas dan menyeluruh dari berbagai aspek, sesuai dengan kapasitas atau petunjuk yang termuat di dalam ayat-ayat yang ditafsirkan tersebut. Artinya penafsiran yang diberikan tidak boleh jauh dari pemahaman ayat-ayat al-Qur'an, agar penafsiran tidak terkesan tersebut berangkat dari pemikiran belaka (al-ra'y al-mahd $)^{17}$. Di dalam penafsiran terhadap satu topik tertentu, tetap menggunakan kaedah-kaedah yang berlaku secara umum di dalam ilmu tafsir, di samping pula dilengkapi dengan dengan hadishadis Nabi, pendapat para sahabat, para ulama dan sebagainya. Dengan demikian, topik yang dibahas harus ditafsirkan harus sampai tuntas, menyeluruh agar memperoleh solusi dari permasalahan yang timbul. Metode tafsir tematik ini dikenal sebagai metode pemecahan masalah dalam bidang ilmu tafsir.

Adapun beberapa langkah dalam metode tafsir ini adalah; pertama, menghimpun ayat-ayat sesuai dengan tema yang akan diangkat dalam penafsiran, sesuai kronologis urutan turunnya; kedua, menelusuri asbab an-nuzul ayat-ayat yang dihimpun; ketiga, memahami dengan cermat semua kata atau kalimat yang dipakai dalam ayat tersebut, terutama kosakata yang menjadi pokok permasalahan, kemudian mengkolerasikan dengan bahasa, budaya, sejarah, munasabat, dhamir, dan sebagainya. Keempat, mengkaji tema tersebut dari berbagai pemahaman aliran maupun pendapat mufasir, baik itu yang klasik maupun yang kontemporer; kelima, tema tersebut kemudian dikaji secara tuntas dan seksama dengan penalaran ilmiah, objektif melalui kaedah-kaedah tafsir yang mu'tabar, serta menghindari dari sikap subjektif penafsir, serta didukung dengan dalil-dalil naqli al-Qur'an, hadis dan fakta-fakta sejarah yang ditemukan. ${ }^{18}$

D. Metode Muqarin (Perbandingan)

Metode Tafsir ini dapat dipahami sebagai bentuk perbandingan; pertama, antara teks (nash) ayat-ayat al-Qur'an yang mempunyai kesamaan/kemiripan kasus, redaksi, atau redaksi yang berbeda tetapi dalam satu kasus yang sama; kedua, membandingkan teks (nash) alQur'an dengan hadis Nabi; dan ketig membandingkan berbagai pendapat ulama dalam menafsirkan ayat-ayat al- Qur'an. ${ }^{19}$

Kajian perbandingan ayat dengan ayat tidak hanya terbatas pada redaksional (mahahits lafdziyyah), tetapi juga kandungan makna dari masing- masing ayat, dan juga kasus yang menjadi tema perbincangan ayat. ${ }^{20}$ Sedang perbedaan pendapat para mufasir, dapat dilihat dari berbagai aspek yang menyebabkan timbulnya perbedaan tersebut, seperti asbab an-nuzul, pemakaian kata dan susunannya dalam ayat berlainan serta konteks masingmasing ayat.

\footnotetext{
${ }^{16}$ Abd al-Farmawi abd al-Hayy, Metode Tafsir Mawdhu'i.., hlm. 36.

${ }^{17}$ Lihat Zhahir bin Awwadah al-Ma'i, Dirasat fi Tafsir al-Maudhu'i (t.tp., tpn., 1405 H), hlm. 7

${ }^{18}$ Abd al-Hayy al-Farmawi, Metode Tafsir Mawdhu'i .., hlm. 52

${ }^{19}$ Zhahir bin Awwadah al-Ma'i, Dirasat fi Tafsir al-Mawdhu'i., hlm. 20.

${ }^{20}$ M. Quraisy Shihab, Tafsir al-Qur'an Dengan Metode Mawdhu'i ..., hlm. 20.
} 
Metode tafsir muqarin ini, baik itu membandingkan ayat dengan ayat, ayat dengan hadits, ataupun para pendapat mufasir, beberapa hal yang perlu dilakukan adalah menentukan ayat tertentu serta melacak berbagai pendapat mufasir tentang ayat tersebut; baik yang salaf maupun yang khalaf, kemudian membandingkan pendapat mereka untuk mengetahui kecenderungan-kecenderungan pemikiran, aliran, keahlian, paradigma, serta faktor apa yang mempengaruhinya. ${ }^{21}$

\section{Bentuk dan Kaidah Penafsiran al-Qur'an}

Bentuk penafsiran al-Qur'an merupakan naw' (macam atau jenis) penafsiran ayat-ayat al-Qur'an. Sepanjang sejarah penafiran al-Qur'an, paling tidak ada tiga bentuk penafsiran yang dipakai oleh ulama; yaitu al-ma'tsur riwayat), al-ra'yi (pemikiran, dan ada sebagian ulama yang menambahkan dengan isyari, meskipun bentuk isyari ini masih menjadi perdebatan/pro kontra dikalangan ulama sendiri.

\section{A. Tafsir bi al-Ma'tsur}

Etimologi kata ma'tsur berasal dari bahasa Arab, atsar yang berarti sunnah, hadis, jejak dan peninggalan. Para mufassir kemudian dinisbatkan pada bentuk penafsiran dengan cara menelusuri jejak atau peninggalan masa lalu dari generasi sebelumnya terus sampai kepada Rasulullah saw. Tafsir bi al-Ma'tsur adalah tafsir yang berdasarkan pada kutipankutipan yang shahih yaitu menafsirkan al-Qur'an dengan al-Qur'an, al-Qur'an dengan sunnah karena ia berfungsi sebagai penjelas Kitabullah, dengan perkataan sahabat karena merekalah yang dianggap paling mengetahui Kitabullah, atau dengan perkataan tokoh-tokoh besar tabi'in karena mereka pada umumnya menerimanya dari para sahabat. ${ }^{22}$

Para sahabat menerima dan meriwayatkan bentuk tafsir seperti ini dari nabi saw secara musyafahat (dari mulut ke mulut), demikian pula masa generasi berikutnya pada masa tadwin (pembukuan), tafsir ini banyak mendapatkan tantangan sebagai bentuk penafsiran. AlZarqani, diantaranya yang membatasi penafsiran bi al-ma'tsur ini hanya penafsiran al-Qur'an yang dilakukan oleh Nabi dan sahabat, karena penafsiran setelah itu telah tercampur dan terpengaruh oleh penikiran israiliyyat, seperti: kisah para Nabi, penciptaan alam, ashhab alkahfi, Madinah Iram, dan lainnya. ${ }^{23}$ Hal yang sama di ungkapkan oleh Imam Ahmad bin Hambal: "ada tiga hal yang tidak punya dasar, yaitu tafsir, kisah perjuangan dan peperangan". ${ }^{24}$ Terlepas dari polemik tentang tafsir bi al-ma'tsur, yang pokok ada dua hal yang menjadi perhatian: pertama, apakah yang dimaksud dengan al- ma'tsur tersebut penafsiran yang diberikan Nabi atau para sahabat; kedua, menafsirkan al-Qur'an dengan bahan-bahan yang diwarisi dari Nabi berupa al- Qur'an, sunnah, dan pendapat para sahabat, menurut al-Hakim nilainya sama dengan hadist marfu'. ${ }^{25}$

Bentuk tafsir bi al-ma'tsur ini merupakan bentuk penafsiran yang mempunyai banyak kelebihan, sebab dalam penafsirannya kebanyakan disandarkan pada perawi-perawi yang

\footnotetext{
${ }^{21}$ Nashruddin Baidan. Metodologi Penafsiran Ayat-Ayat yang Beredaksi Mirip di Dalam al-Qur'an. Cet. Ke-2. (Pekanbaru: Fajar Harapan, 1993), hlm. 191.

${ }^{22}$ Thameem Ushama, Metodologi Tafsir al-Qur'an, Ibid., hlm. 5.

${ }^{23}$ Muhammad 'Abd al-Azhimal-Zarqani, Manahilal-'Irfan fi 'Ulumal-Qur'an. Cet. Ke- I (Mesir: Isa alBab al-Halabi, t.th), hlm. 23.

${ }^{24}$ Nashruddin Baidan, Rekonstruksi Ilmu Tafsir ........., Ibid., hlm. 52.

${ }^{25}$ Hadist al-marfu' adalah istilah untuk hadist yang langsung diterima dari Nabi, baik dalam bentuk perkataan, perbuatan dan ketetapan (taqrir); Ajaj al-Khatib, Ushul al-Hadist (t.tp., Dar al-Fikr, 1975), hlm. 355.
} 
disifatkan pada para sahabat. Sebagian metode tafsir ini mengungkapkan cerita-cerita para rasul beserta sifat-sifat mereka dan kitab-kitab yang diturunkan kepada mereka serta mu'jizat-mu'jizat mereka. Sedangkan beberapa kelemahan dalam bentuk penafsiran ini adalah; ${ }^{26}$ pertama, banyak riwayat-riwayat yang disisipkan oleh musuh-musuh Islam seperti yang disisipkan oleh orang-orang zindiq, baik dari bangsa Yahudi maupun Persi. Kedua, usaha-usaha yang dilakukan oleh penganut-penganut madzhab yang terlalu jauh menyimpang dari kebenaran; ketiga, bercampur baurnya riwayat yang shahih dengan yang tidak shahih dan banyaknya perkataan-perkataan yang tidak disandarkan kepada sahabat atau tabi'in tanpa menyebut sanad dan tanpa menyaring sehingga tercampurlah antara yang hak dan bathil. Keempat, riwayat- riwayat Israiliyat $^{27}$ yang mengandung dongeng-dongeng yang tidak dapat dibenarkan. Kelima, terhadap nukilan-nukilan kitab lama, hendaklah kita bersikap tidak menolak dan tidak menerima, karena mungkin kutipan dari kitab lama tersebut telah berubah dari teks aslinya atau bahkan masih seperti aslinya. Beberapa contoh karya Tafsir bi al-ma'tsur yang terkenal antara lain: Tafsir Ibnu Jarir, Tafsir Abu Laits asSamarkandy, Tafsir ad-Dararul Ma'tsur fit Tafsiri bil Ma'tsur, karya Jalaluddin as-Suyuthi, Tafsir Ibnu Katsir, Tafsir al-Baghawy dan Tafsir Baqy ibn Makhlad, Asbabun Nuzul, karya al-Wahidy dan an-Nasikh wal-Mansukh, karya Abu Ja'far an-Nahhas.

Contoh menafsirkan ayat al-Qur'an dengan ayat al-Qur'an antara lain: “Wa kuluu wasyrabuu hattaa yatabayyana lakumul khaithul abyadhu minal khaithil aswadi minal fajri...", surat al-Baqarah: 187. Kata minal fajri adalah tafsir bagi apa yang dikehendaki dari kalimat al-khaithil abyadhi. Sedangkan contoh menafsirkan ayat al-Qur'an dengan Sunnah Nabi antara lain: "Alladziina aатапии wa lam yalbisuu iimaanahum bizhulmin..." (surat alAn'am: 82). Rasulullah saw menafsirkan dengan mengacu pada ayat: "innasy syirka lazhulmun 'azhiim" (surat Luqman: 13). Dengan itu Beliau menafsirkan makna zhalim dengan syirik.

B. Tafsir bi ar-Ra'yi

Seiring perkembangan zaman yang menuntut pengembangan metode tafsir karena tumbuhnya ilmu pengetahuan pada masa Daulah Abbasiyah maka tafsir ini memperbesar peranan ijtihad dibandingkan dengan penggunaan tafsir bi al- ma'tsur. ${ }^{28}$ Dengan bantuan ilmu-ilmu bahasa Arab, ilmu qiraah, ilmu-ilmu al- Qur'an, hadits dan ilmu hadits, ushul fikih dan ilmu-ilmu lain seorang mufasir akan menggunakan kemampuan ijtihadnya untuk menerangkan maksud ayat dan mengembangkannya dengan bantuan perkembangan ilmuilmu pengetahuan yang ada.

Tafsir bi al-ra' yi mengalami perkembangan pesat, namun ulama menerimapendekatan tafsir ini menjadi dua, yaitu ulama yang memperbolehkan, dan yang kedua ulama yang melarangnya. Tetapi pada kenyataannya kedua pendapat tersebut hanya bersifat lafzhi (redaksional), yaitu mereka sama-sama mencela penafsiran berdasarkan ra'yi (pemikiran) semata tanpa mengindahkan kaedah- kaedah dan kriteria yang berlaku dalam penafsiran. ${ }^{29}$

\footnotetext{
${ }^{26}$ Muhammad Husayn al-Dzahabi, Penyimpangan-Penyimpangan Dalam Penafsiran al-Qur'an, Terj. Muhammad Abdullah Saman (Jakarta: Raja Grafindo Persada, tt), hlm. 15.

${ }^{27}$ Quraisy Shihab, Wawasan al-Qur'an, Ibid., hlm. 164.

28 Taufik Adnan Amal dan Syamsul Rizal Panggabean, Tafsir Kontekstual al-Qur'an, Cet. Ke-3 (Bandung: Mizan, 1992), hlm. 18.

${ }^{29}$ Nashruddin Baidan, Rekonstruksi Ilmu Tafsir, Ibid., hlm. 58.
} 
Hal ini dikarenakan, dengan penafsiran bi al-ra'yi akan terbawa pada bentuk takhmin (spekulasi, atau terkaan) dan tidak mu'tabarah dalam menafsirkan al-Qur'an, mengingat hanya didasarkan pada kekuatan nalar manusia.

Istilah ra'yu dekat maknanya dengan ijtihad, kebebasan penggunaan akal yang didasarkan pada prinsip-prinsip yang benar, menggunakan akal ayng sehat dan persyaratan yang ketat. Tafsir bi ar-ra'yi adalah tafsir yang di dalam menjelaskan maknanya mufasir hanya berpegang pada pemahaman sendiri dan penyimpulan (istinbat) yang didasarkan pada ra'yu semata. Sedangkan tafsir bi ar-ra'yi ini terdiri dalam dua kategori yaitu; pertama, tafsir terpuji (mamduhah), bentuk tafsir al-Qur'an yang didasarkan pada ijtihad yang jauh dari kebodohan dan penyimpangan. Tafsir ini sesuai dengan pertuturan bahasa Arab, karena tafsir ini bergantung pada metodologi yang tepat dalam memahami ayat-ayat al-Qur'an. Kedua, tafsir yang tercela (madzmumah); bentuk tafsir al-Qur'an yang tidak dibarengi dengan pengetahuan yang benar, yaitu tafsir yang hanya didasarkan pada keinginan (al-hawa) seseorang dengan mengindahkan berbagai peraturan dan persyaratan tata bahasa serta kaidah-kaidah hukum Islam. ${ }^{30}$ adapun beberapa contoh dari bentuk tafsir bi ar-ra'yi yang terkenal antara lain: Tafsir al-Jalalain (karya Jalaluddin Muhammad al-Mahally dan disempurnakan oleh Jalaluddin Abdur Rahman as-Suyuthi), Tafsir al-Baidhawi, Tafsir alFakhrur Razy, Tafsir Abu Suud, Tafsir an-Nasafy, Tafsir al-Khatib, dan Tafsir al-Khazin.

Contoh Tafsir bi ar-ra'yi dalam Tafsir Jalalain: "Khalaqal insaana min 'alaq", (surat al-'Alaq ayat 2). Kata 'alaq disini diberi makna dengan bentuk jamak dari lafaz 'alaqah yang berarti segumpal darah yang kental.

C. Tafsir Isyari

Tafsir Isyari adalah bentuk penafsiran ayat-ayat al-Qur'an yang mengabaikan makna dhahirnya, tetapi berdasarkan indikasi (isyarat) yang dapat diterima oleh sebagian orang yang sadar dan berpengalaman atau tampak bagi orang yang memiliki akhlak terpuji dan melawan hawa nafsu mereka. Pikiran dan wawasan mereka telah diilhami dan disinari oleh Allah, maka mereka telah melakukan dan merealisasikan rahasia-rahasia al-Qur'an. Oleh karenanya, Allah telah mengisyaratkan membuka jalannya dengan meleburkan sumber-sumber pengetahuan eksternal dan internal (lahir-batin) dari ayat-ayat al-Qur'an. ${ }^{31}$ Dengan kata lain, tafsir isyari mengacu pada penafsiran lain selain makna eksternal dan yang tampak dari teks.

Tafsir isyari bukanlah ilmu pengetahuan biasa yang diperoleh melalui penelitian dan belajar, tetapi ilmu yang diberikan langsung oleh Allah dengan jalan intuisi mistik melalui dzikir yang terus-menerus kepada Allah; pengaruh taqwa, istiqamah, dan salat ${ }^{32}$ sebagaimana dalam al-Qur'an,“.... dan bertaqwalah kepada Allah; Allah akan mengajarmu..." (Qs 2: 82). Sedangkan beberapa karya tafsir Isyari yang terkenal antara lain: Tafsir an-Naisabury, Tafsir al-Alusy, Tafsir at-Tastary, Tafsir Ibnu Araby. Contoh bentuk penafsiran secara isyari antara lain adalah pada ayat:“....Innallaha ya'murukum an tadzbahuu baqarah...." (surat al- Baqarah: 67). Ayat tersebut mempunyai makna zhahir adalah“.....Sesungguhnya Allah menyuruh kamu menyembelih seekor sapi betina ...” tetapi dalam tafsir Isyari diberi makna dengan“....Sesungguhnya Allah menyuruh kamu menyembelihnafsu hewaniah...".

\footnotetext{
${ }^{30}$ Thameem Ushama, Metodologi Tafsir al-Qur'an......., Ibid., hlm. 5

${ }^{31}$ Muhammad Ali Sabuni, al-Tibyan fi' Ulum al-Qur'an, (Dar al-Irshad: Beirut, 1970), hlm. 78

${ }^{32}$ Thameem Ushama, Metodologi Tafsir al Qur'an $\quad$,Ibid., hlm. 22.
} 
Tafsir merupakan ilmu yang membahas tentang cara pengucapan lafazh-lafazh alQur'an, tentang petunjuk-petunjuknya, hukum-hukumnya baik ketika berdiri sendiri maupun ketika tersusun dan makna-makna yang dimungkinkan baginya ketika tersusun serta hal-hal lain yang melengkapinya. Oleh karena itu, dalam penafsiran al-Qur'an perlu adanya pemahaman yang mendalam tentang kaidah-kaidah bahasa, pemahaman asas-asasnya, penghayatan uslub-uslubnya dan penguasaan rahasia-rahasianya. ${ }^{33}$ Sedangkan Ibnu Katsir dalam mukadimah Tafsir-nya menyatakan tentang kaidah menafsirkan al-Qur'an: pertama, menafsirkan al-Qur'an dengan al-Qur'an. Metodologi ini merupakan yang paling shahih (valid). Kedua, menafsirkan al-Qur'an dengan sunah, karena sunah merupakan pensyarah dan menjelaskan al-Qur'an. Ketiga, menafsirkan al-Qur'an dengan perkataan para sahabat, sebab mereka adalah orang-orang yang lebih mengetahui sekaligus sebagai saksi dari berbagai fenomena dan situasi yang terjadi seputar al-Qur'an (asbab an-nuzul). Keempat, bila tidak didapati camenafsirkan dengan ketiga metode di atas, maka menafsirkan al-Qur'an dengan pemahaman yang dimiliki para tabi'in (murid-murid para sahabat). ${ }^{34}$

\section{Ta'wil Dan Metode Memahami Al-Qur'an Lainnya}

Ta'wil berbeda dengan tafsir. Tafsir berasal dari kata al-fusru yang mempunyai alibanah wa al-kasyf (menjelaskan dan menyingkap sesuatu). Dalam pengertian secara definitifnya, tafsir adalah ilmu untuk memahami kitabullah yang diturunkan kepada nabi Muhammad saw menjelaskan makna-maknanya serta mengeluarkan hukum, pelajaran dan hikmahnya. Hal ini sejalan dengan surat al- Furqan ayat 33, "Wa laa ya'tuunaka bimatsalin illaa ji'naaka bil haqqi wa ahsana tafsiiran".

Sedang ta'wil berasal dari kata aul, yang berarti kembali ke asal. Pengertian secara definitifnya ta'wil merupakan pemahaman atau pemberian pengertian atas fakta-fakta tekstual dari sumber-sumber suci al-Qur'an dan hadis sedemikian rupa, sehingga dapat diperlihatkan bukan makna lahiriyah kata-kata pada teks tersebut, tetapi pada makna dalam (batin/inward meaning) yang dikandungnya. ${ }^{35}$ Para ulama menyepakati bahwa terdapat perbedaan diantara keduanya, tetapi tafsir dan ta'wil penting dalam proses penafsiran alQur'an, yaitu : pertama,tafsir dan ta'wil adalah dua kata yang mempunyai kedekatan atau sama maknanya, sebab ta'wil esensi yang dimaksud dari suatu perkataan dan menjelaskan maknanya. Kedua, ta'wil esensi yang dimaksud dari suatu perkataan atau esensi sesuatu yang berada dalam realita, sedangkan tafsir merupakan syarah dan penjelasan bagi suatu perkataan dan penjelasan ini berada dalam pikiran dengan cara memahaminya dan dalam lisan dalam ungkapan yang menunjukannya. Ketiga, tafsir adalah apa yang telah jelas di dalam Kitabullah atau tertentu (pasti/qath'i) dalam Sunnah yang shahih karena maknanya telah jelas dan gamblang, sedang ta'wil apa yang disimpulkan ulama, karena ta'wil merupakan apa yang berhubungan dengan dirayah. Keempat, tafsir lebih banyak digunakan dalam menerangkan lafazh dan mufradat (kosakata), sedang ta'wil lebih banyak dipakai untuk menjelaskan makna dan susunan kalimat. ${ }^{36}$

Sedangkan metode memahami al-Qur'an selain ilmu tafsir dan ta'wil, juga ada

\footnotetext{
${ }^{33}$ Manna Khalil al-Qattan, Studi Ilmu-Ilmu Qur'an.........,Ibid., hlm. 278.

${ }^{34}$ Imam al-Fida al-Hafizh Ibn Katsir, Tafsir al-Qur'an al- 'Azhim (Beirut: Dar al-Fikr, 1992), hlm. 4.

${ }^{35}$ Quraisy Shihab, Membumikan al-Qur'an (Bandung: Mizan, 1992), hlm. 143.

${ }^{36}$ Manna Khalil al-Qattan. Studi Ilmu-Ilmu Qur'an................... Ibid, hlm. 260.
} 
hermeneutika sebagai sebuah metode interprestasi sangat releven kita pakai dalam memahami pesan al-Qur'an agar subtilitas intilitas intelegendi (ketetapan pemahaman) dan subtilitas ecsplicandi (ketepatan penjabaran) dari pesan Allah bisa ditelusuri secara komprehensif. Maksudnya, pesan Allah yang diturunkan pada teks al-Qur'an melalui Nabi Muhammad itu tidak hanya kita pahami secara tekstual, juga bisa kita pahami secara kontekstual dan menyeluruh dengan tidak membatasi diri pada teks dan konteks ketika alQur'an beserta yang melingkupinya dapat digunakan agar selaras dan cocok dengan kondisi ruang, waktu, dan tempat di mana kita berada dan hidup. Artinya, al-Qur'an telah menjadi wahyu yang ditulis, dikodifikasi dalam bahasa Arab. Karena al-Qur'an merupakan diskursus yang ditulis, maka al-Qur'an adalah teks. Pandangan ini sejalan dengan penganut hermeneutika atau studi tentang penafsiran, bahwa setiap diskursus yang disusun atau disempurnakan dalam bentuk tulisan disebut teks. ${ }^{37}$ Diskursus hermeneutika tidak bisa kita lepaskan dari bahasa, karena problem hermeneutika adalah problem bahasa. ${ }^{38}$ Karena itu, dalam memahami teks al- Qur'an, disamping harus memahami kaidah tataq bahsa, juga mengandaikan suasana psikologis dan sosio historis (wacana) yang teks tersebut atau hubungan yang dialektis antara teks dan wacana.

Dalam dunia bahasa semiotika dianggap sebagai tanda (sign) yang terdiri dari unsur yang tidak bisa dipisahkan, yaitu penanda (signifiant) dan petanda (signify). Penanda adalah aspek material dari bahasa sedangkan petanda adalah makna (konsep/concept) yang ada dalam pikiran (mind). Bahasa adalah metafor, sehingga makna yang ditimbulkan selalu bergerak dan berubah sesuai dengan horison pembacaan, tidak ada makna final bagi bahasa. Berangkat dari logika ini, kalau bahasa agama merupakan kumpulan teks-teks (tanda) sudah semestinya ia tidak mengenal akhir. Disinilah semiotika mempunyai peran yang signifikan, dimana teks-teks bahasa agama menjadi subur untuk menemukan pemahaman- pemahaman baru guna mengaktualisasikan pesan Islam yang universal dan membawa misi rahmatan lil'alamin. ${ }^{39}$

Jadi, teks-teks agama (lughat), termasuk al-Qur'an tidak terpisah dari struktur budaya tempat ia terbentuk, mengingat teks dan budaya saling mempengaruhi, budaya mempengaruhi teks, yang kemudian melahirkan paradigma "budaya sebagai faktor determinan atas teks", atau muntajun tsaqafiyyun, atau sebaliknya al-Qur'an dalam perjalanannya telah mengubah budaya Arab yang kemudian dikenal "teks sebagai produsen budaya" atau muntijun tsaqafiyyun. ${ }^{40}$ Kedua teori ini hendak menjelaskan bahwa al-Qur'an adalah wahyu yang bersifat dinamis, progresif dan "shalih likuli zaman wa makan". Sumber teks sama sekali tidak mengesampingkan hakikat keberadaannya sebagai teks linguistik dengan segala implikasi kebahasaanya. Teks terkait dengan ruang dan waktu dalam pengertian historis dan sosiologis. Teks tidak berada di luar kategori bahasa sehingga tidak memiliki kaitan apapun dengan manusia. Jika berinteraksi dengan teks agama ini bertolak

\footnotetext{
${ }^{37}$ Paul Ricoeur, Hermenutics and Human Sciences, edited and translated by John B. Thompson, Cambridge University Press, New York, 1981, hlm. 145.

${ }^{38}$ Nasr Hamid Abu Zayd, Hermenatika Insklusif (Jakarta: ICIP, 2004), hlm. 34; Lihat juga K. Bertens, Filsafat Barat Kontemporer Perancis (Jakarta: Gramedia, 2001), hlm. 197. 1996), hlm. 31.

${ }^{39}$ Komaruddin Hidayat, Memahami Bahasa Agama: Sebuah kajian Hermeneutik (Jakarta: Paramadina,

${ }^{40}$ Nasr Hamid Abu Zayd: Mafhum an-Nash: Dirasat fi 'Ulum al-Qur'an, al-Markaz al- Araby alTsaqafi, Beirut, Libanon, 1996, hlm. 24
} 
dari keberadaannya sebagai linguistik, maka ini tidak berarti mengabaikan watak tekstualitasnya yang spesifik. Sebab karakter tekstualitas al-Qur'an didasarkan pada realitasrealitas kemanusiaan yang provan, yang bersifat sosiologis, kultural, dan kebahasaan. ${ }^{41}$ Keberadaan firman Tuhan yang kudus baru menjadi perhatian hanya pada momen dimana "kalam tersebut diposisikan secara manusiawi", ketika Muhammad mengujarakannya dalam bahasa Arab.

Disinilah kita memahami al-Qur'an sebagai sebuah diskursus ${ }^{42}$ akan membantu kita untuk mengawinkan antara dimensi teks dan dimensi konteks, karena keduannya harus disandingkan sebagai sebuah kenyataan faktual dalam teks. Memisahkan teks dan konteks akan mengakibatkan hilangnya entitas al- Qur'an sebagai kitab suci yang mengandalkan kekuatan utamanya pada susunan kalimat dan pesan kemanusiaan. Karenanya, untuk menjadikan al-Qur'an sebagai teks terbuka harus melalui dua jalur, yaitu teks dan konteks. Dengan cara tersebut al-Qur'an akan menggugah nalar dan kesadaran umat Islam dalam upaya melanjutkan apa yang telah dicapai oleh para ulama terdahulu, untuk menjadikan alQur'an sebagai sumber kemajuan, bukan sumber kemunduran dan kekerasan yang hampir melanda dunia Islam.

\section{KESIMPULAN}

Al-Qur'an sebagai kitab suci umat Islam merupakan sumber hukum dan petunjuk serta menjelaskan segala sesuatunya secara komprehensif dan metode praktis bagi kehidupan. Oleh karena itu perlu adanya ilmu perlu adanya ilmu tafsir dengan maksud agar menuntut para mufasir dalam proses penafsiran al-Quran sehingga tidak keluar dari apa yang dimaksudkan oleh al-Qur'an sendiri. Selain itu mufasir mengerti kaidah-kaidah yang harus dipakai dalam penafsiran, serta dituntut menguasai/memahami jati diri al-Qur'an baik itu bentuk penafsiran (tafsir bi al-ma'tsur, tafsir bi al-ra'yi, dan tafsir isyari), metode (ijmali, muqarin, maudhu'i, tahlili), corak dan juga kepribadian yang luhur, baik dan bertanggungjawab. Selain itu tafsir dan ta'wil yang ada sejak zaman Rasulullah saw seiring dengan kemajuan zaman bermunculan metode pendekatan baru dalam memahami al-Qur'an seperti: hermeneutik dan pendekatan kajian analisis bahasa (linguistik), yaitu semiotik.

\section{DAFTAR PUSTAKA}

Abu Zayd, Nasr Hamid, Mafhum an-Nash: Dirasat fi 'Ulum al-Qur'an, al-Markazal-'Araby al-Tsaqafi, Beirut, Libanon, 1996.

, Hermeneutika Inklusif. Jakarta: ICIP, 2004.

Al-Farmawi, Abd al-Hayy. Metode Tafsir Mawdhu'i. Suatu Pengantar. Terj. Suryan A. Jumrah, cet. Ke-2. Jakarta: Raja Grafindo, 1996Ajaj al-Khatib, Ushul al-Hadist, t.tp., Dar al-Fikr, 1975.

Al-Azhim al-Zarqani, Muhammad 'Abd, Manahil al-'Irfan fi 'Ulum al-Qur'an. Cet. Ke-I, Mesir: Isa al-Bab al-Halabi, t.th.

\footnotetext{
${ }^{41}$ K.Bertens, Filsafat Barat , Ibid., hlm. 199.

${ }^{42}$ Zuhairi Misrawi, Al-Qur'an Kitab Toleransi......, Ibid., hlm. 85.
} 
Amal, Taufik Adnan dan Panggabean. Syamsul Rizal. Tafsir Kontekstual al-Qur'an, cet. Ke-3. Bandung: Mizan, 1992.

Ash-Shiddiqiey, Hasbi. Ilmu-ilmu al-Qur'an. Media-Media Pokok DalamMenafsirkan alQur'an. Jakarta: Bulan Bintang, 1993.

Baidan, Nashruddin. Metodologi Penafsiran Ayat-Ayat yang beredaksi Mirip diDalam alQur'an. Cet. Ke-2. Pekanbaru: Fajar Harapan, 1993. , "Rekonstruksi Ilmu Tafsir”, dalam Pidato Pengukuhan Guru Besar Madya Ilmu Tafsir. Surakarta: 1999

Pelajar, 1998

Metodologi Penafsiran al-Qur'an, cet. Ke-1. Yogyakarta: Pustaka

Bertens, K.Filsafat Barat Kontemporer Perancis. Jakarta: Gramedia, 2001.

Dhahabi, Muhammad Husayn, al-Ijtihad al-Munharifat fi Tafsir al-Qur'an al-Karim. First Edition. Tanpa Kota: Dar al-I’tisam, 1976.

Penyimpangan-Penyimpangan Dalam Penafsiran al-Qur'an,

Terj. Muhammad Abdullah Saman. Jakarta: Raja Grafindo Persada, tt Jakarta: Paramadina, 1996.

Hidayat, Komaruddin. Memahami Bahasa Agama: Sebuah Kajian Hermeneutik. Jakarta: Paramadina, 1996.

Ibn Katsir, Imam al-Fida, al-Hafizh. Tafsir al-Qur'an al- 'Azhim. Beirut: Dar al- Fikr, 1992.

Khalil al-Qattan, Manna'. Studi Ilmu-Ilmu Qur'an, Terj. Mudzakir AS, cet. V. Bogor: Pustaka Litera Antarnusa. 1996.

Misrawi, Zuhairi, Al-Qur'an Kitab Toleransi. Inklusivisme, Pluralisme dan Multikulturalisme, Jakarta: Penerbit Fitrah, 2007.

Ricoeur, Paul, Hermenutics and Human Sciences, edited and translated by John B.Thompson, Cambridge University Press, New York, 1981.

Sabuni, Muhammad, Ali. Al-Tibyan fi- 'Ulum al-Qur'an. Dar al-Irsyad: Beirut, 1970.

Shihab, Quraisy. "Tafsir al-Qur'an Dengan Metode Mawdhu'i”, dalam Beberapa Aspek Ilmiah Tentang al-Qur'an. Penyunting KH. Bustami A. Gani, Cet. Ke-1. Jakarta: Perguruan Tinggi al-Qur'an Press, 1986.

, Wawasan al-Qur'an. Bandung: Mizan, 1996.

, Membumikan al-Qur'an, Bandung: Mizan, 1992.

Ushama, Thameem. Metodologi Tafsir al-Qur'an. Kajian Kritis, Objektif dan Komprehensif. Jakarta: Riara Cipta, 2000. 